\title{
Preventive treatment of sun-damaged skin: Topical treatment of actinic keratosis can prevent surgery in non- melanoma-skin-cancer
}

\section{Daisy Kopera* \\ Department of Dermatology, Medical University Graz, Austria}

Sun damaged skin sooner or later develops Actinic Keratosis (AK) representing an early stage of non-melanoma skin cancer (NMSC). The lesions appearing as reddish or brownish, rough, and sometimes scaly macules evolve from UV-damaged keratinocytes. They slowly progress to invasive squamous cell carcinoma by the ability to grow in three dimensions: (1) horizontal growth along the basal cell layer, or (2) vertical growth in two directions either "upwards" within the epidermis, or (3) "downwards" invading papillary dermal layers [1,2] (Figure 1). There is no chronological order within these three growingdirections and AK may therefore become invasive at all stages of progression (AK 1, AK 2, or AK3) [3].

\section{Progression of AK into invasive SCC}

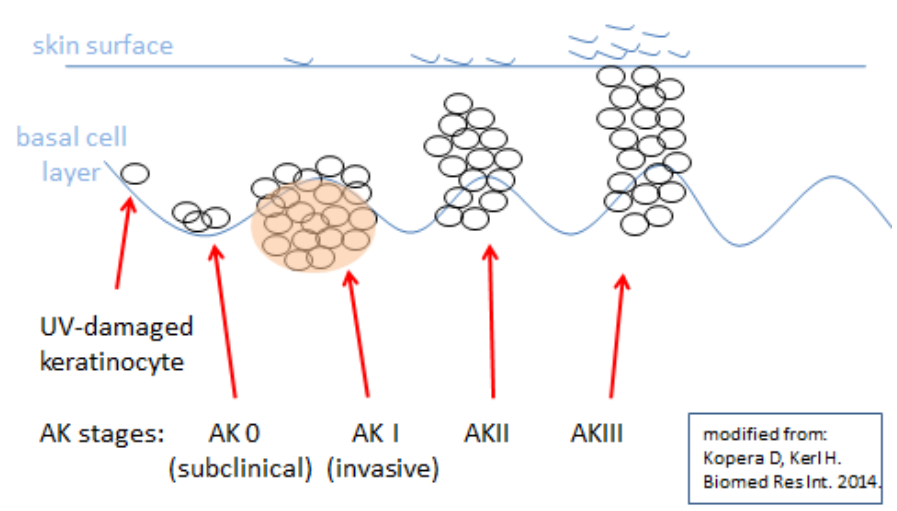

Figure 1. Progression of AK into invasive SCC

Copyright: (C2017 Kopera D. This is an open-access article distributed under the terms of the Creative Commons Attribution License, which permits unrestricted use, distribution, and reproduction in any medium, provided the original author and source are credited.
Immuno-modulationg substances like Imiquimod and Ingenolmebutat have been approved for the topical treatment of AK by the European Medical Agency (EMA) [4]. As AK may grow invasively at all stages, their topical treatment is also indicated at very early stage.

Furthermore these observations give room for discussion regarding preventive treatment of sun-damaged skin with topical immuno-modulators to avoid non-melanoma-skin cancer. This has been suggested by the authors illustrated by a case report and a pilot study $[2,5,6]$.

\section{References}

1. International League of Dermatological Societies (ILDS) Evidence-based (S3) Guidelines for the treatment of Actinic Keratosis. [http://debm.de/uploads/AK-GL draft_3_methods.pdf]

2. Kopera D, Kerl H (2010) Detection and treatment of preclinical actinic keratoses (PAK). J Dtsch Dermatol Ges 8: 693-694. [Crossref]

3. Fernandez-Figueras MT, Carrato C, Sáenz X, Puig L, Musulen E, et al. (2014) Actinic keratosis with atypical basal cells (AK i) ist he most common lesion associted with invasive squamous cell carcinoma oft he skin. J Europ Acad Dermatol Venereol 29: 991-997. [Crossref]

4. [http://www.ema.europa.eu/docs/en_GB/document_library/EPAR_Public assessment_report/human/002387/WC500132263.pdf]

5. Kopera D, Kerl H (2014) Visualization and treatment of subclinical actinic keratoses with topical imiquimod 5\% cream: an observational study. Biomed Res Int: 135916. [Crossref]

6. Kopera D, Goswami N, Kerl H (2016) AK progressing to NMSC: at what stage? J Eur Acad Dermatol Venereol 30: e172-e173. [Crossref]
Correspondence to: Daisy Kopera, MD, MBA, Department of Dermatology, Medical University Graz, Auenbruggerplatz 8, 8036 Graz, Austria, Tel: +43316-385-12423, E-mail: daisy.kopera@medunigraz.at

Received: December 16, 2017; Accepted: December 26, 2017; Published: December 29, 2017 